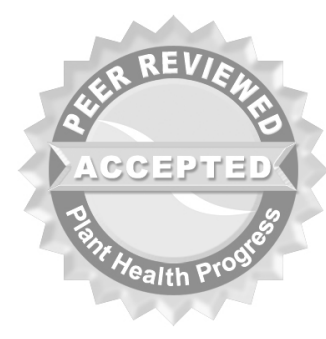

(C) 2010 Plant Management Network.

Accepted for publication 19 October 2009. Published 15 February 2010.

\title{
Etiology of Peanut Pod Rot in Nicaragua: I. The Effect of Pod Size, Calcium, Fungicide, and Nematicide
}

\author{
J oao Augusto, Former Graduate Research Assistant, \\ Timothy B. Brenneman, Professor, and Alexander S. Csinos, \\ Professor, Department of Plant Pathology, University of Georgia \\ Coastal Plain Experiment Station, Tifton, GA 31793
}

Corresponding author: Joao Augusto. jaugusto@uga.edu

Augusto, J., Brenneman, T. B., and Csinos, A. S. 2010. Etiology of peanut pod rot in Nicaragua: I. The effect of pod size, calcium, fungicide, and nematicide. Online. Plant Health Progress doi:10.1094/PHP-2010-0215-01-RS.

\begin{abstract}
Pod rot is one of the most important peanut (Arachis hypogaea L.) diseases in the pacific coast region of Cosiguina in Nicaragua. The region receives excessive rainfall during the peanut growing season and fields with high pod rot incidence often have moderate to high infestations of stem rot (Sclerotium rolfsii) and lesion nematode (Pratylenchus spp.). It was hypothesized that soilborne fungi, nematode damage and/or soil calcium deficiency could be involved in peanut pod rot. Flutolanil (1.2 kg a.i./ha, two applications), aldicarb (3.4 kg a.i./ha, one application), and calcium (670 kg/ha, two applications of gypsum) were evaluated on small (Georgia Green) and large (C-99R) seeded, runner cultivars in field experiments from 2005 to 2007 to help determine disease etiology. Experiments were split-split-plot or split-plot designs and treatments were replicated five times. There were no differences in pod rot between the two cultivars. Flutolanil did not decrease pod rot and only increased yield when associated with aldicarb nematicide. Gypsum application did not decrease pod rot, or increase yield or pod calcium content. Aldicarb had no effect on pod rot, but significantly increased yield by $22 \%$, apparently by suppression of pod and/or root damage by lesion nematode. Neither calcium deficiency nor lesion nematode damage increased pod rot.
\end{abstract}

\section{I ntroduction}

Pod rot is one of the most important diseases affecting peanut production in Nicaragua. The disease is more prevalent in the pacific coast region of Cosiguina, as well as in Chinandega and Leon to a lesser extent. Peanut pod rot symptoms include brown to dark discoloration of the pericarp and pegs that usually begins at the apical pod tip and extends to the basal pod segment and peg. In addition to rotted pods, pegs often disintegrate and pods are lost in soil, further contributing to a yield reduction (7).

Preliminary observations in locations with high pod rot incidence in Nicaragua showed that lesion nematode populations were often high. Laboratory assays of pods with symptoms of lesion nematode damage (Fig. 1) indicated densities of 1456 to 2462 Pratylenchus spp. per $5 \mathrm{~g}$ of shells of Georgia Green. Lesion nematode injury can best be identified by the presence of small tan spots with dark centers on pods. The lesion nematode is common in the warmer climates of the world similar to that of Nicaragua, and can be found in large numbers inside the shells of mature peanut pods and pegs (15), where they colonize dark-colored, necrotic lesions (10). In a heavily infested field, Good et al. (10) found that peanut shells of a runner cultivar contained from six to eight times as many P. brachyurus nematodes as did the roots. The nematode feeds within the parenchymatous tissues, weakening the pegs and pods, and is recognized as an economically important pathogen of peanut in most production regions of the world (17). Although other nematode species have been implicated in the pod rot complex of peanut (8), no literature is available for pod rot caused by interactions between Pratylenchus spp. and 
fungi. Nevertheless, Good et al. (10) found that in fields heavily infested by P. brachyurus, $19 \%$ of pods were left in the ground at digging because of weakened or rotted pegs associated with heavy infection by lesion nematode. Conversely, only $6 \%$ of the pods were left in soil in plots treated with nematicide. Since many fields with pod rot in Nicaragua also had high populations of lesion nematodes, it was important to determine the relationship between lesion nematode damage, peanut pod rot, and yield.

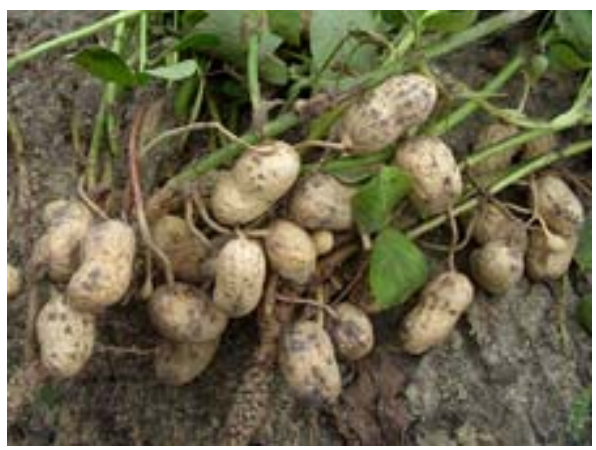

Fig. 1. Lesion nematode damage on peanut pods caused by Pratylenchus spp. in Cosiguina, Nicaragua.

Stem rot (Sclerotium rolfsii) is another important soilborne peanut disease in fields with pod rot prevalence in Nicaragua. Sclerotium rolfsii infects lower stems, roots, pegs, and pods during peanut pod formation and maturation, or earlier, and may cause pod rot (16) (Fig. 2). The association between S. rolfsii and other fungi in peanut pod rot has been reported as well (12), but not between S. rolfsii and Pratylenchus spp. nematodes. Flutolanil, a benzanilide fungicide, is registered for use on peanut and effective against S. rolfsii and Rhizoctonia solani (4), another fungal species isolated from pod rot samples from peanut fields in Nicaragua. Other isolated fungal species and their significance to peanut pod rot in these fields are discussed in a second manuscript of this series (2).

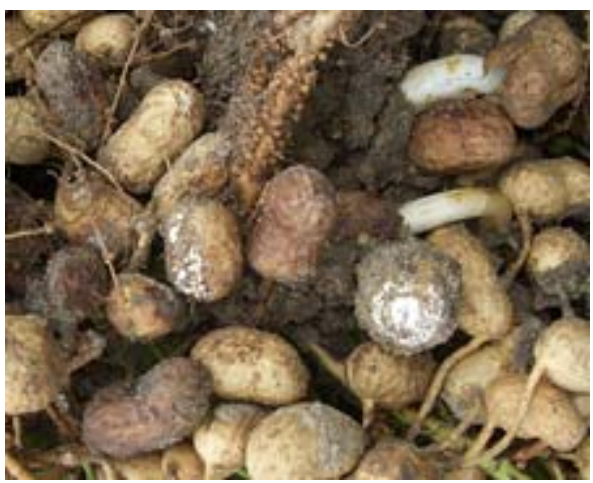

Fig. 2. Peanut pod rot caused by Sclerotium rolfsii in Cosiguina, Nicaragua. Note the uniform discoloration of infected pods, sclerotial initials of $\mathrm{S}$. rolfsii, and the premature seed sprouting, which are typical of pod rot associated with S. rolfsii.

Another factor that has been shown to play a significant role in the peanut pod rot complex is low level of available calcium in soil (5), especially in largeseeded cultivars $(9,11,14)$. Sumner et al. (18) indicated that pod surface area and surface to volume ratio were important in determining the quantity of calcium in seed and explains why large seeded varieties are more sensitive to calcium deficiency. Georgia Green, a small-seeded runner type, is the standard peanut cultivar in Nicaragua. However, other peanut cultivars with different pod and 
seed sizes are being introduced to the country. Nearly all of the new cultivars have larger pods than Georgia Green (809 to 875 seeds $/ \mathrm{kg}$ ), with one of the largest being C-99R (605 to 678 seeds $/ \mathrm{kg}$ ). Due to its larger seed size, C-99R should be more susceptible than Georgia Green to pod rot induced by calcium deficiency. The relative susceptibility of these new cultivars to pod rot and comparing a large versus small-seeded cultivar would be an indicator of the importance of calcium nutrition to pod rot development in Nicaragua.

The objectives of the study were to understand the etiology of pod rot in Nicaragua, and to determine the effect of cultivar selection, fungicide, nematicide, and gypsum applications on pod rot and peanut pod yield.

\section{Cultivar Selection and Fungicide, Nematicide, and Gypsum Treatments}

Field experiments were conducted in seven locations in Cosiguina and one location in Leon regions in Nicaragua from 2005 to 2007 to evaluate the effect of cultivars (small-seeded Georgia Green and large-seeded C-99R), flutolanil, aldicarb, and gypsum applications on pod rot control and peanut pod yield. These inputs were chosen to selectively control factors known to cause pod rot, and identify those with the greatest impact in Nicaragua. Sclerotium rolfsii and R. solani were suspected to cause pod rot of peanut in Nicaragua, and flutolanil is one of the most effective fungicides used for disease control (4). Aldicarb is labeled for use on peanuts to control nematodes. It also has activity on thrips, but thrips damage has not been observed on peanuts in Nicaragua. Applications of gypsum were evaluated as a source of calcium, and were repeated to compensate for leaching by heavy rainfall.

Fields were selected based on past occurrences of pod rot and high populations of lesion nematodes. The fields were prepared by disk plowing 20 to $25 \mathrm{~cm}$ deep and disk harrowing three times before planting. The experimental design was either a split-split-plot or split-plot with treatments replicated five times. Each plot consisted of double beds (two twin rows per bed), the left bed for pod yield and the right bed for destructive sampling for nematode and pod rot assessments. Plots were $10 \mathrm{~m}$ long and separated by a 3$\mathrm{m}$ fallow alley. Georgia Green and C-99R were planted with a twin-row Cole planter at 23 to 26 seeds $/ \mathrm{m}$. Row spacing was $109.2 \mathrm{~cm}$ between the outside rows and $73.7 \mathrm{~cm}$ between the inside rows.

In split-split-plot experiments, the whole-plot factor was fungicide, the subplot factor was nematicide, and the sub-sub-plot factor was gypsum. In the split-plot experiments, the whole-plot factor was cultivar and sub-plot factor was nematicide. Fungicide treatments were: flutolanil (1.2 kg a.i./ha); and nontreated control. Nematicide treatments were: aldicarb (3.4 kg a.i./ha); and nontreated control. Gypsum treatments were: at beginning pod ( $\mathrm{R}_{3}, 50$ to 60 DAP) and beginning seed (R5, 80 to 90 DAP), as defined by Boote (3), with application of $670 \mathrm{~kg} / \mathrm{ha}$ each time; and nontreated control.

The gypsum was applied by hand in a $50-\mathrm{cm}$ band centered over the row without incorporation. The field sites had a medium level of extractable calcium with ammonium acetate extraction method (6) prior to planting $(7.8,7.6$, and $7.4 \mathrm{meq} \mathrm{Ca} / 100 \mathrm{~g}$ soil in 2005, 2006, and 2007, respectively), but it was hypothesized that soil calcium deficiency might occur during pod formation and maturation by leaching of calcium during excessive rainfall or the calcium being in an unavailable form.

Flutolanil was applied at the same times as gypsum with a $\mathrm{CO}_{2}$-beltpack sprayer delivering 189 liter/ha at 31 psi by four 11004 tips with 50 mesh screens per bed. Aldicarb was applied after planting, but before seedling emergence, with a Gandy applicator in a 30-cm band centered over the row and lightly incorporated with a rake. Standard production practices were applied uniformly to the field, including regular sprays with chlorothalonil (1.26 kg a.i./ha) for control of leaf spots and peanut rust. Plots were not fertilized or irrigated during the growing seasons.

Pod rot incidence was determined by counting the number of intact and rotted pods collected from plants in 1-m sections of each bed. Rotted pods left 
in soil were manually excavated and included in counts. Since some pods would have been destroyed before harvest at full maturity, this evaluation was conducted approximately 100 DAP. Disease incidence was obtained by dividing the number of rotted pods by total number of pods in a section and multiplying by 100 . Three 1-m sections were sampled in each plot, and the final disease incidence was an average of the three sections. In locations with high counts of lesion nematode, five 2.5 -cm-diameter by $10-\mathrm{cm}$-deep soil cores were collected from the geocarposphere (1) of each plot within 2 weeks before peanut digging to determine nematode populations. In addition to soil samples, peanut pods (50 to 100 pods per plot) were collected during the same time period. Soil and pod samples were placed in plastic bags and transported in coolers to the LAQUISA Laboratorios Quimicos, S.A. (Carretera Leon, Managua km 83, Apartado 154, Leon, Nicaragua) for analysis of populations of plant-pathogenic nematodes. The nematode extraction procedure from soil was by the Baerman funnel method as described by Hooper (13). The extraction of nematodes from shells of pod samples was by the Baerman funnel method (10). Lesion nematodes were identified and counted using a stereo binocular microscope. A diagnostic key (15) was used for proper identification of nematode genus, but species were not determined. Only nematode counts of Pratylenchus spp. in shells are presented and discussed in this paper as counts of the other nematodes in shells and soil samples were inconclusive.

The left bed of each plot was mechanically dug and inverted with a KMC digger/inverter at about 130 to 150 DAP for yield assessment. Windrows were mechanically harvested with a two-row combine within 2 weeks. The final pod moisture content after air-drying was approximately $8 \%$ (wt/wt), and peanut yield was determined after removing foreign material. At digging, samples of 50 to 100 pods/plot were collected and sent to the LAQUISA laboratory for determining calcium content in shells and seed. Calcium content was analyzed by Mehlich No. 3 method previously described by Tucker (19).

The Statistical Analysis System PROC MIXED (SAS Institute Inc., Cary, NC) was used to analyze variation of nematode counts (especially Pratylenchus spp.), pod rot incidence, peanut pod yield, and calcium content in shells and seed in response to the treatments and cultivars. The interaction of year $\times$ location $\times$ treatments for nematode counts, pod rot, pod yield, and calcium content in shells and seed was used to determine if data could be pooled across years and locations. The Protected LSD $(\alpha=0.05)$ was used for mean separations among treatments.

Field experiments to evaluate the effect of nematicide and cultivars on pod rot and yield were conducted at two locations in Cosiguina in 2005 (Table 1). Neither cultivar nor aldicarb affected pod rot incidence, and both small-seeded Georgia Green and the large-seeded C-99R had relatively high pod rot. This experiment was not repeated in 2006 and 2007 because of the limited availability of seed for C-99R. In addition, grower cooperators had little interest in growing $\mathrm{C}-99 \mathrm{R}$ because it yielded significantly lower than Georgia Green.

Table 1. Effect of small-seeded (Georgia Green) and large-seeded (C-99R) cultivars and nematicide on pod rot and peanut pod yield in two fields at Cosiguina in 2005.

\begin{tabular}{|l|l|c|c|}
\hline \multirow{4}{*}{ Cultivar } & Nematicide & $\begin{array}{c}\text { Pod rot incidence } \\
(\%)\end{array}$ & $\begin{array}{c}\text { Peanut pod yield } \\
(\mathrm{kg} / \mathrm{ha})\end{array}$ \\
\hline \multirow{3}{*}{ Georgia Green } & aldicarb & 20.4 & $5766 \mathrm{a}$ \\
\cline { 2 - 4 } & none & 24.1 & $5611 \mathrm{a}$ \\
\hline \multirow{2}{*}{ C-99R } & aldicarb & 22.7 & $4701 \mathrm{~b}$ \\
\cline { 2 - 4 } & none & 29.9 & $4689 \mathrm{~b}$ \\
\hline LSD & ns & 742 \\
\hline
\end{tabular}

$x$ Means within a column with the same letter are not significantly different according to the LSD test $(a \leq 0.05)$.

ns: Indicates that means within a column are not significantly different according to ANOVA ( $a \leq 0.05)$. 
Multivariate analysis of variance across tests indicated that the number of Pratylenchus spp. nematodes in shells and pod rot incidence were both negatively correlated to pod yield. In contrast, calcium content in shells and total pod calcium were positively correlated to pod yield. However, the number of Pratylenchus spp. in shells and calcium content in shells and seed were not correlated to pod rot (Table 2).

Table 2. Partial correlation coefficients of pod calcium, Pratylenchus spp. count in shells, pod rot and pod yield in trials according to multivariate analysis of variance using Proc GLM SS3 of SAS. ${ }^{x}$

\begin{tabular}{|l|l|l|}
\hline DF $=\mathbf{2 8}$ & \multicolumn{1}{|c|}{ Pod rot } & Peanut pod yield \\
\hline Calcium in shells & $r=-0.164104$ & $r=0.258731$ \\
& $\mathrm{P}=0.3950$ & $\mathrm{P}=0.0502$ \\
\hline Calcium in seed & $\mathrm{r}=-0.051677$ & $\mathrm{r}=0.194462$ \\
& $\mathrm{P}=0.7901$ & $\mathrm{P}=0.3121$ \\
\hline Total calcium (shells plus seed) & $\mathrm{r}=-0.020752$ & $\mathrm{r}=0.247172$ \\
& $\mathrm{P}=0.9149$ & $\mathrm{P}=0.0511$ \\
\hline Pratylenchus spp. nematodes & $\mathrm{r}=0.16914$ & $\mathrm{r}=-0.288370$ \\
per 5 g of shells & $\mathrm{P}=0.1337$ & $\mathrm{P}=0.0376$ \\
\hline Pod rot & 1.000000 & $\mathrm{r}=-0.501955$ \\
& & $\mathrm{P}=0.0310$ \\
\hline
\end{tabular}

$x$ Partial correlation coefficients and probabilities between variables were from eight trials in Cosiguina and Leon regions from 2005 to 2007, $r=$ partial correlation coefficient, $\mathrm{P}=$ probability value.

Application of aldicarb with or without flutolanil and calcium decreased $(\mathrm{P}=0.027)$ the number of Pratylenchus spp. in shells. Aldicarb alone decreased the number of Pratylenchus spp. in shells by $73 \%$ compared to control plots. Application of aldicarb with or without flutolanil and calcium also increased $(\mathrm{P}=0.044)$ pod yield compared to nontreated control plots (Table 3$)$. However, aldicarb did not decrease pod rot and it had no effect on calcium content in shells and seed.

Table 3. Effect of fungicide, nematicide, and gypsum applications on pod (shell and seed) calcium, Pratylenchus spp. counts, pod rot and pod yield from five trials in Cosiguina and one trial in La Leona (Leon), 2005 to 2007. w

\begin{tabular}{|c|c|c|c|c|c|c|c|c|}
\hline \multirow{2}{*}{$\begin{array}{l}\text { Fung- } \\
\text { icide }\end{array}$} & \multirow{2}{*}{$\begin{array}{l}\text { Nemat- } \\
\text { icide }\end{array}$} & \multirow[b]{2}{*}{ Gypsum } & \multicolumn{3}{|c|}{$\begin{array}{c}\text { Calcium content } \\
(\%)\end{array}$} & \multirow{2}{*}{$\begin{array}{c}\text { Number of } \\
\text { Pratylenchus } \\
\text { spp. per } 5 \mathrm{~g} \\
\text { of shells }\end{array}$} & \multirow{2}{*}{$\begin{array}{c}\text { Pod } \\
\text { rot } \\
(\%)\end{array}$} & \multirow{2}{*}{$\begin{array}{c}\text { Peanut } \\
\text { pod } \\
\text { yield } \\
(\mathrm{kg} / \mathrm{ha})\end{array}$} \\
\hline & & & shell & seed & total & & & \\
\hline \multirow[t]{4}{*}{ flutolanil } & \multirow[t]{2}{*}{ aldicarb } & yes & 0.24 & 0.07 & 0.31 & $599 b$ & 24.0 & 5691 a \\
\hline & & no & 0.19 & 0.07 & 0.26 & $700 \mathrm{~b}$ & 24.9 & $5414 a b$ \\
\hline & \multirow[t]{2}{*}{ none } & yes & 0.22 & 0.08 & 0.30 & $2292 a$ & 27.2 & 4888 bc \\
\hline & & no & 0.20 & 0.07 & 0.27 & $2031 \mathrm{a}$ & 27.5 & 4859 bc \\
\hline \multirow[t]{4}{*}{ none } & \multirow[t]{2}{*}{ aldicarb } & yes & 0.22 & 0.07 & 0.29 & $535 b$ & 25.2 & $5306 a b$ \\
\hline & & no & 0.19 & 0.07 & 0.26 & $655 b$ & 25.9 & $5156 a b$ \\
\hline & \multirow[t]{2}{*}{ none } & yes & 0.22 & 0.08 & 0.30 & $2377 a$ & 29.8 & 4824 bc \\
\hline & & no & 0.19 & 0.06 & 0.25 & 2462 a & 32.0 & $4409 c$ \\
\hline \multicolumn{3}{|l|}{ LSD } & ns & ns & ns & 998 & ns & 744 \\
\hline
\end{tabular}

${ }^{\mathrm{w}}$ Georgia Green cultivar was planted at 23 to 28 seeds $/ \mathrm{m}$.

$x$ Pod samples were collected at digging. Total calcium content refers to calcium in shells plus seed.

y Samples were collected 2 weeks prior to digging.

$\mathrm{z}$ Means in columns with the same letter(s) are not significantly different according to the protected LSD ( $a \leq 0.05$ ).

ns: Indicates that means within a column are not significantly different according to ANOVA ( $a \leq 0.05)$. 
Flutolanil increased pod yield only when accompanied by aldicarb irrespective of gypsum application. Flutolanil did not decrease pod rot and it had no effect on pod calcium content and nematode counts (Table 3).

Gypsum applications at beginning pod $\left(\mathrm{R}_{3}\right)$ and beginning seed $\left(\mathrm{R}_{5}\right)$ had no effect on pod rot, nematode counts, or pod yield. Applications of gypsum generally made little difference in pod calcium content (Table 3).

\section{Conclusions}

While stem rot is an important disease in these fields and S. rolfsii can be a very effective pod rot pathogen, the results indicated that it played only a minor role in peanut pod rot in these trials. The results also indicated that infection and damage by Pratylenchus spp. can be significant and justifies further research, but apparently the damage is not associated with pod rot symptoms. The lack of a differential response of pod rot to gypsum in the small-seeded or large-seeded cultivar provided evidence that calcium deficiency was not a primary cause of pod rot in these fields. However, there was a positive correlation between pod yield and calcium content in shells and total pod calcium. This may have been due to smaller, positive effects on peanut seed quality or grade that were not of large enough magnitude to impact pod rot.

Overall, this study indicated that factors other than calcium deficiency, nematode damage, or S. rolfsii are causing the majority of pod rot. Another common cause of pod rot is infection by Pythium spp., and data presented in the second paper of this series indicates that this pathogen was a primary cause of pod rot in Nicaragua (2).

\section{Acknowledgments}

Funding for the research was provided by the Association of Peanut Growers of Nicaragua. The authors would like to thank Diego Jerez, Mario Hurtado, and Ramiro Saborio for the field work.

\section{Literature Cited}

1. Alva, A. K., Gascho, G. J., and Guang, Y. 1991. Soil solution and extractable calcium in gypsum-amended coastal plain soils used for peanut culture. Commun. Soil Sci. Plant Anal. 22:99-116.

2. Augusto, J., Brenneman, T. B., and Csinos, A. S. 2010. Etiology of peanut pod rot in Nicaragua: II. The role of Pythium myriotylum as defined by applications of gypsum and fungicides. Online. Plant Health Progress doi:10.1094/PHP-2010O215-O2-RS.

3. Boote, K. J. 1982. Growth stages of peanut (Arachis hypogaea L.). Peanut Sci. 9:3540.

4. Csinos, A. S. 1987. Control of southern stem rot and Rhizoctonia limb rot of peanut with flutolanil. Peanut Sci. 14:55-58.

5. Csinos, A. S., and Gaines, T. P. 1986. Peanut pod rot complex: A geocarposphere nutrient imbalance. Plant Dis. 70:525-529.

6. Doll, E. C., and Lucas, R. E. 1973. Testing soils for potassium, calcium and magnesium. Pages 133-151 in: Soil Testing and Plant Analysis. L. M. Walsh and J. D. Beaton, eds. Soil. Sci. Soc. Am., Madison, WI.

7. Filonow, A. B., Melouk, H. A., Martin, M., and Sherwood, J. 1988. Effect of calcium sulfate on pod rot of peanut. Plant Dis. 72:589-593.

8. Garcia, R., and Mitchell, D. J. 1975. Synergistic interactions of Pythium myriotylum with Fusarium solani and Meloidogyne arenaria in pod rot of peanut. Phytopathology 65:832-833.

9. Garren, K. H. 1964. Land plaster and soil rot of peanut pods in Virginia. Plant Dis. Reptr. 48:349-352.

10. Good, J. M., Boyle, L. W., and Hammons, R. O. 1958. Studies of Pratylenchus brachyurus on peanuts. Phytopathology 48:530-535.

11. Higgins, B. B. 1954. Black pod. Page 31 in: Growing Peanuts. J. H. Beattie, F. W. Poos, and B. B. Higgins, eds. Farmers' Bull. 2063 USDA, Washington, DC.

12. Hollowell, J. E., Shew, B. B., Beute, M. K., and Abad, Z. G. 1998. Occurrence of pod rot pathogens in peanuts grown in North Carolina. Plant Dis. 82:1345-1349.

13. Hooper, D. J. 1990. Extraction and processing of plant and soil nematodes. Pages 45-68 in: Plant Parasitic Nematodes in Subtropical and Tropical Agriculture. M. Luc, R. A. Sikora, and J. Bridge, eds. CAB Intl., Wallingford, UK. 
14. Lewis, P. I., and Filonow, A. B. 1990. Reaction of peanut cultivars to Pythium pod rot and their influence on populations of Pythium spp. in soil. Peanut Sci. 17:9095.

15. Mai, W. F., and Mullin, P. G. 1996. Plant Parasitic Nematodes: A Pictorial Key to Genera. W. F. Mai, P. G. Mullin, H. H. Lyon, and K. Loeffler, eds. Cornell University Press, Ithaca, NY.

16. Porter, D. M., Smith, D. H., and Rodriguez-Kabana, R. 1982. Peanut plant diseases. Page 326-410 in: Peanut Science and Technology. H. E. Pattee, and C. T. Young, eds. Proc. Am. Peanut Res. Educ. Soc., Yoakum, TX.

17. Sasser, J. N., and Freckman, D. W. 1987. A world perspective on nematology: The role of the society. Pages 7-14 in: Vistas on Nematology: A Commemoration of the 25th Anniversary of the Society of Nematologists. J. A. Veech, and D. W. Dickson, eds. Soc. of Nematol., Inc., Hyattsville, MD.

18. Sumner, M. E., Kvien, C. S., Smal, H., and Csinos, A. S. 1988. Calcium nutrition of peanut (Arachis hypogaea L.) I. Conceptual model. J. Fertilizer Issues 5:97-102.

19. Tucker, M. R. 1992. Determination of potassium, calcium, magnesium, and sodium by Mehlich 3 extraction. Pages 9-12 in: Reference Soil and Media Diagnostic Procedures for the Southern Region of the United States. S. J. Donohue, ed. Southern Cooperative Series Bull. No. 374. Virginia Agric. Exp. Station, Blacksburg, VA. 